\title{
河道内高木群落の形成過程 STUDY ON FORMATION AND GROWTH OF REVERINE TREES
}

\author{
茂木信祥 $^{1} \cdot$ 須賀堯二 $^{2} \cdot$ 池田裕一 $^{3}$ \\ Nobuyoshi MOGI, Kyozo SUGA, Hirokazu IKEDA \\ 1 学生会員 宇都宮大学大学院 工学研究科（广321-8585 宇都宮市陽東 7 丁目） \\ 2フエロー員 工博 宇都宮大学教授 工学部建設学科 （T321-8585 宇都宮市陽東 7 丁目） \\ ${ }^{3}$ 正会員 博(工) 宇都宮大学助教授 工学部建設学科（广321-8585 宇都宮市陽東 7 丁目）
}

\begin{abstract}
Field survey was carried out in order to clarify such important ecological aspects of trees in Kinu-Rivar as appropriate felling of trees, tree planting, and management of trees. In this study, investigation was made as to realities of growth condition of trees, secular changes and characteristics of tree environment by differences in cannel characteristics, and hydraulic conditions.

And the following results were obtained as relations between the stages of growth speed of trees and dominant species, the direction of spread of trees, the effect of bed material characteristics, and the effect of inundation.
\end{abstract}

Key Words : trees, trees community, growth speed of trees, channel characteristics, bed material, inundation frequency

\section{1. はじめに}

河道内高木は，洪水流下への支障，新規の流木生産源 となる恐れ, 流木やゴミの捕捉など, 治水状の阻害要因 として排除されてきたが, 生態系への育成環境ポテンシ ヤル，河川公園機能，景観上の効果，流水に対する而侵 食性などの有効な機能が評価されるようになった. その 結果, まちづくり等の関連で堤防小段の桜並木や, 高水 敷の植樹など人工的な植樹带についての検討が処々で行 われ，実施例も增大し，反対に伐採は減少している.

こうしたなか, 植生に関する研究としては, 植物生態 学の分野では森林動態の変動の予測はおおむね明らかに されている ${ }^{1)}$. 一方, 最近河川工学の分野でも, 河道内 における河川固有の植生動態のモデル化を視野にいくつ か研究がなされている. 剛部ら 2) の研究は, 河状履歴を 表す指標と植生調查により, 河状と植生の相互関係を明 らかにし, 李ら ${ }^{3)}$ の植生繁茂と土砂堆積作用の関係につ いての研究では, 磷床裸地が安定した植生域をもつに至 るシナリオを明らかにしている. ただし, 両研究とも流 水自体による群落破壊とその後の構造の変化については 触れていない. また, 砂田ら ${ }^{4)}$ の研究は, 中長期的な植 生の存在状態を予測·評価する手法について提示してい
るが，樹種や立体的構造が考慮されていない，そこで本 研究では，河川敷内の高木に関する新しい知見を得るた めに, 鬼怒川河道を対象として, 河川敷における高木の 育成状況の実態, 経年变化, 河道特性や水理条件の違い による高木群落構造の相違等について調査し, 河道内高 木の形成と発展について基礎的な検討を行った.

\section{2. 対象河川の概要}

対象河川とした鬼怒川は，利根川の支川であり，その 流域面積は $1,761 \mathrm{~km}^{2}$, 河道延長は $176 \mathrm{~km}$ であり, 流域面 積のうち山地が約 $65 \%$, 平地が $35 \%$ を占める. 現況河 道は男体山と女峰山からの右支川大谷川を経ての土砂流 出の影響を強く受けており, 大谷川との合流地点 $(110 \mathrm{~km}$ 地点付近）から上流では，本川は陕谷をなし，堤防や護 岸などの工作物はほとんどない5).

図-1 に流況の経年変化として, 平方 (37. $3 \mathrm{~km}$ 地点) の 年最大流量を示す. 過去 30 年間における平均年最大流量 は $1,200 \mathrm{~m}^{3} / \mathrm{s}$ である. 1983 年以降大きな出水はなく,変動 の幅が減少していることが分かる．これは，降雨状況な ど自然的要因のほかに, 川治ダム (1983 年竣工, 治水容 量 3,600 万 $\mathrm{m}^{3}$ ) 等による洪水調節（調節流量 $2,600 \mathrm{~m}^{3} / \mathrm{s}$, うち川治ダム $1,400 \mathrm{~m}^{3} / \mathrm{s}$ ） の効果もあると考えられる. 


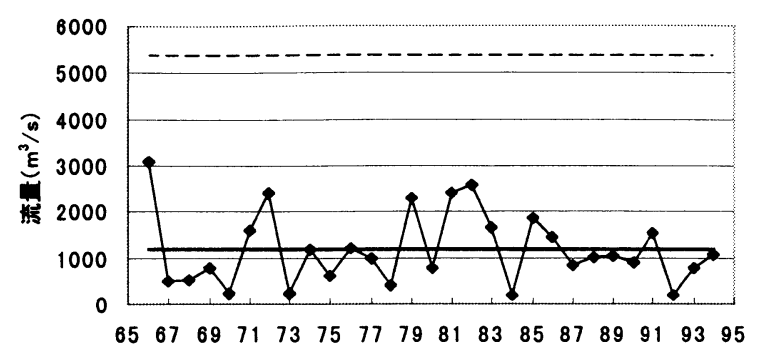

西厢

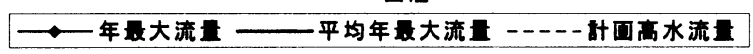

図-1 年最大水深 (平方 $37.3 \mathrm{~km}$ )

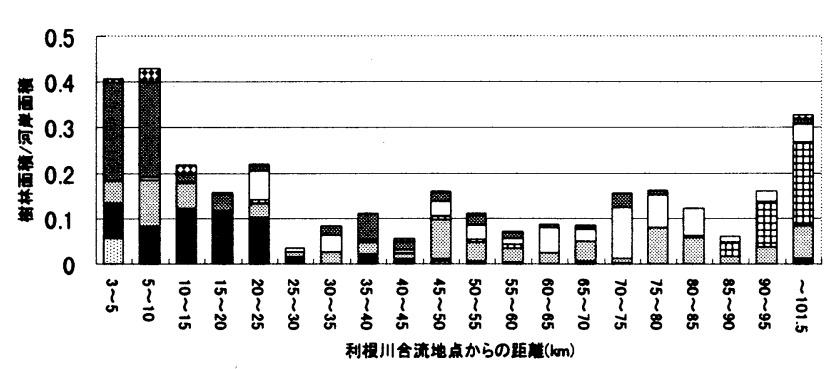

國シラかシロヤナギロコナラ曲アカマツロハリエンジュロ多䅡

図-2 鬼怒川の樹種概要

次に，鬼怒川の植生に関する河川水辺の国勢調查年鑑 (1995 年） ${ }^{6}$ によると, 鬼怒川の河川敷の植生は出水の 破壊作用を受けやすいため極めて不安定である. 冠水頻 度の高い部分では, 裸地あるいはイヌタテ, ハハコグサ 等の草本植物が優占し, 冠水頻度の比較的少ない半安定 部では, ヨシ, ツルヨシ, オギ等の高茎草本がみられ, 更に冠水頻度の少ない立地では土㗒も形成されヤナギ, クヌギ, ハリエンジュ等の木本群落もみられる. 植物種 においては, 103 科 508 種類が確認され，高木群落につい ては，図-2より，下流部ではヤナギやモウソウチク・マダ ケ等が多くみられ，上流域ではアカマツ，全域にわたっ て, コナラ, ハリエンジュがみられる. また, 1995 年に おける鬼怒川河道内における植被度（全植生地面積/水面 を除く河道内面積) は, 左岸側で 0.68 , 右岸側で 0.73 と なっている. また, 植生地面積内の高木地と草本地の比 は, 左岸で高木地 0.14 , 草本地 0.86 , 右岸で高木地 0.20 , 草本地 0.80 となっている.

\section{3. 調査地点の概要と調査方法}

調查地点は, 河道特性を考虑し, 表-1 に示す 4 地点で 行った. 今回は, 河道特性, 育成条件の大きく異なる上 流部網流蛇行区間と下流部複断面区間の状況について報 告を行う.

\section{(1) 上流部網流蛇行区間5)}

川幅は 500-1,100m, 河床勾配は 1/100-1/300, 河床材 料は玉石混じりの砂利であり, 横侵食性河道のため多様 な変化が見られる．この区間は，峡谷部からの本流の第
表-1 調查地点

\begin{tabular}{|c|c|c|}
\hline \multicolumn{1}{|c|}{ 河道特性 } & $\begin{array}{c}\text { 利根川合流地点 } \\
\text { からの距離( }(\mathrm{km})\end{array}$ & 河床勾配 \\
\hline 上流部網流蛇行区間 & 92.0 & $1 / 190$ \\
\hline 上流部 2 列蛇行区間 & 68.0 & $1 / 390$ \\
\hline 上流部単列蛇行区間 & 55.0 & $1 / 480$ \\
\hline 下流部核断面区間 & 29.0 & $1 / 2130$ \\
\hline
\end{tabular}
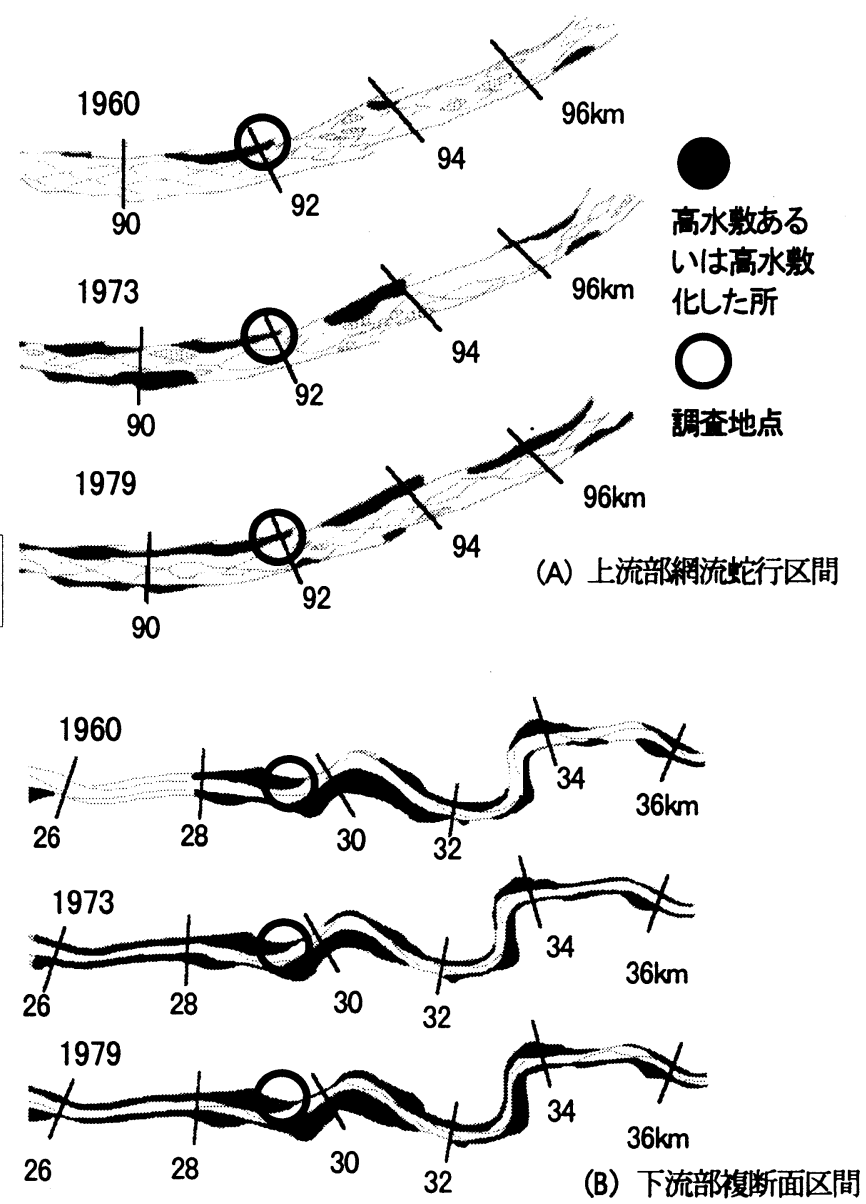

図-3 低水路幅と砂州の経年変化

一次減勢区間である. 調査地点付近は，図-3（A）の低水 路幅と砂州の経年変化から判断すると, 低水路の固定と 高水敷化が進んでいることがわかる.これは, 河床低下 により低水路が鮮明化したためである. また，砂州も低 水路幅の縮小に伴い, 不安定な網流砂州から複列砂州に 変化している.

\section{(2) 下流部複断面区間5)}

川幅は 180-400m, 河床勾配は 1/1,000-1/2,000, 河床 材料は砂である. また, 河道横断形は複断面であり, 両岸 は連続堤になっている. 調查地点では, 図-3（B）より高 水敷の幅が経年的に狭くなる傾向が見られる.これは河床 低下や低水護岸等による低水路の固定化に起因する. 砂州 は単列砂州を形成しており, 1973 年と 1979 年の砂州の形 状はほぼ同一である。 


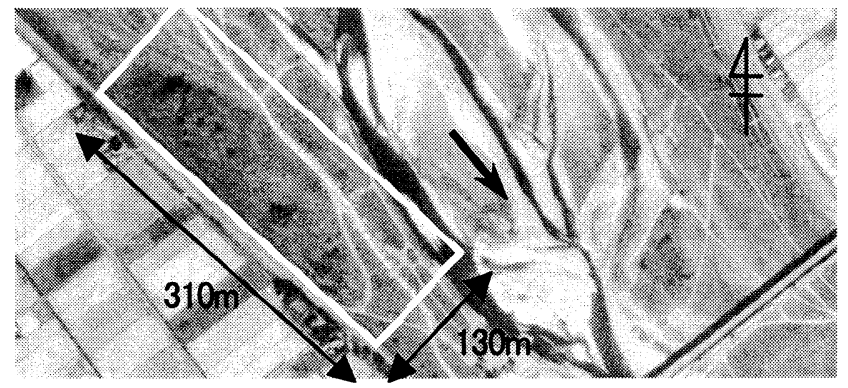

図-4 上流部網流蛇行区間の空中写真

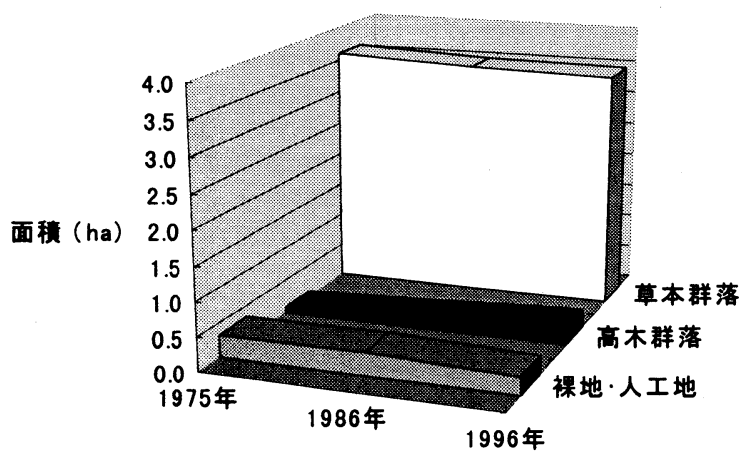

図-5 上流部網流蛇行区間の植生経年変化

\section{（3）調查方法}

現地調査は，各調查地点において，樹種，高木群落面 積, 樹高, 立木密度, 年輪, 河床材料, 樹冠, 根茎調査 および空中写真による経年変化の調査を行った. また, 年輪調査については, 高木群落において代表的な高木に ついて成長錐を用いて行った.

\section{4. 鬼怒川河道の高木群落の実態}

\section{(1) 上流部網流蛇行区間（92.0km 地点右岸）}

上流部網流蛇行区間の毎木調查を行った地点は，面積 0.96ha, 群落の内の樹数（樹齢 10 年以上）は約 130 本, 調查地内の立木密度は 2.3 本/ $/ \mathrm{m}^{2}$ であった. 立木密度が大 きいことについては，幼木が多いためと考えられる．ま た樹林地内の樹種は，2 種により構成されており, 優占 種であるハリエンジュが7割，コゴメヤナギが 3 割を占 めていた.

図-5 は，図-4 の実線で囲まれた調查地点付近の植生の 経年変化を空中写真から判読したものを示したものであ る. この図より, 空中写真から判読した地点における高 木群落の植被度は, 1975 年で $2.1 \%, 1986$ 年で $5.7 \%, 1996$ 年では $6.9 \%$ となっており，増加の傾向にあることが分か る. また, この地点では, 1958 年に一度大きな出水があ ったものの, それ以後の出水は確認されておらず，平水 位に対する群落地点の地盤高の差（比高）も, 平均 $2.1 \mathrm{~m}$ 之高い. 図-3(A)からもわかるように，この地点は高水敷 が固定化しており, この地点では, 洪水などの水理的影 響がないと考えられる.

図-6 は，南-北，西-東，南西-北東，南東-北西の 4 方 向の樹㱓分布を示したものである. それぞれ各方向で初 期植生域と思われるもっとも樹㱓の大きい部分を中心に,
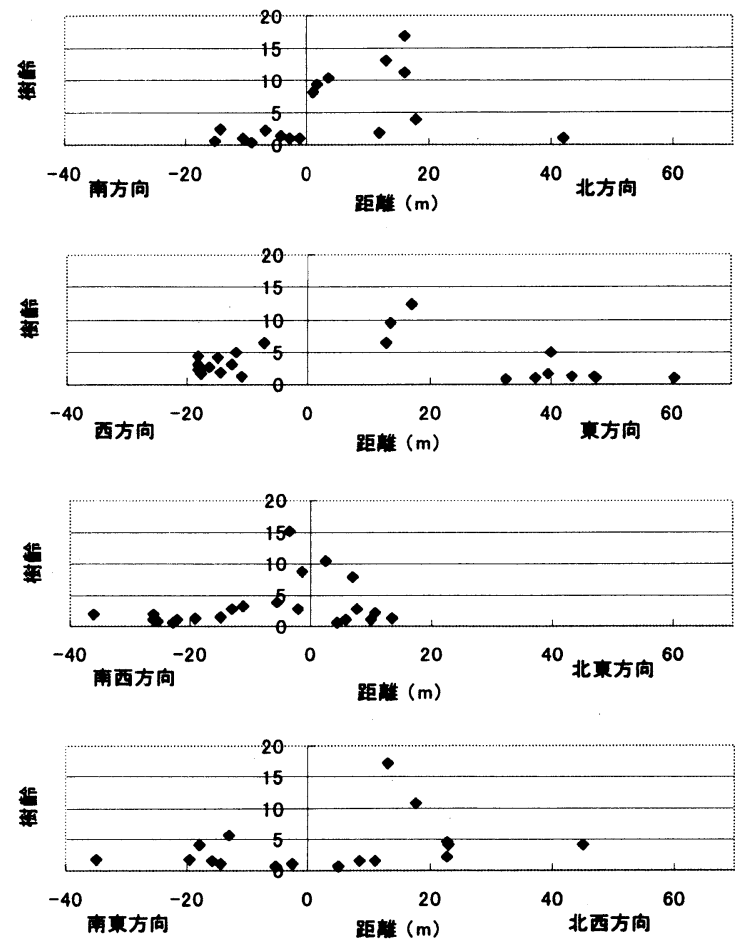

図-6 樹齢分布 （上流部網流蛇行区間）

距離が増すごとに樹㱓が小さくなっている. また，高木 群落の分布範囲を見ると, 西-東, 南東-北西方向が広く, この方向に高木群落が拡大していると考えられる. この 拡大傾向の理由として, 過去この地点で 30 年間で, 高木 群落が冠水するような大きな出水が確認されていないこ とから, 幼木の育成を阻害する要因がなく, 南西方向は, 河床材料が值径 $20 \mathrm{~cm}$ ほどの玉石であり, 北東方向は, 高 茎草本であるヨシが密生しているため, この方角には拡 大しにくいと考えられる. さらに，この群落の優占種で あるハリエンジュの繁殖の方法は，地下茎や根などの先 から芽を出して繁殖する栄養繁殖であると同時に, 種子 を生産し繁殖する. 栄養繁殖の場合, 根茎調查により拡大 方向に法則性はなく，栄養繁殖による樹数は，立木密度 から推定すると全体の $85 \%$ であった. よって, 群落全体 の桩大方向を決める要因としては，種子散布によるとこ ろが大きいと考えられ，この地点の場合，散布時の風向 が流下方向（南東方向）であったためこのような拡大傾 向となったと考えられる.

図-7，8 は，高木の成長速度を明らかにするために, この地点の代表的な樹種であるハリエンジュとコゴメヤ ナギの樹齢と胸高直径, 樹高の関係を示したものである. 樹齢と胸高直径, 樹高の関係は, 両者とも対数で表され る. 樹齢は 5 年でハリエンジュは, 樹高 $5.5 \mathrm{~m}$, 直径 $0.09 \mathrm{~m}$ 程度に成長し, コゴメヤナギは, 樹高 $3.2 \mathrm{~m}$, 直径 $0.06 \mathrm{~m}$ 程度に成長することがわかる. よって, ハリエンジュの ほうが初期成長速度は速いことになる.このように，い くつかの樹種が群落内にある場合, 優占種となるのは, 初 期成長速度の速い樹種であることがわかる． また，曲線 の特徵を見ると，コゴメヤナギは，樹㱓と共に胸高周長 が増加していくが, ハリエンジュは樹龄 10 年から成長速 


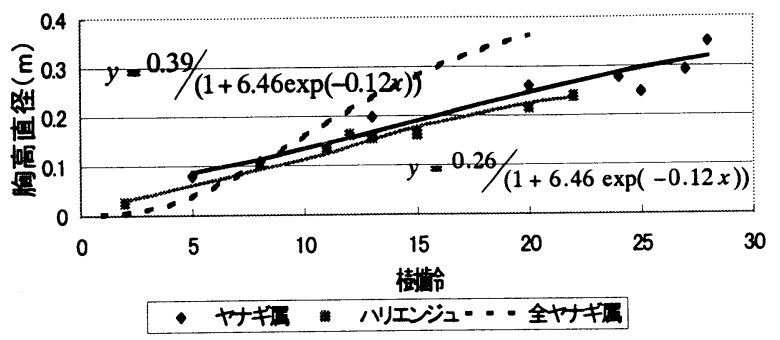

図-7 樹齢と胸高直径の関係

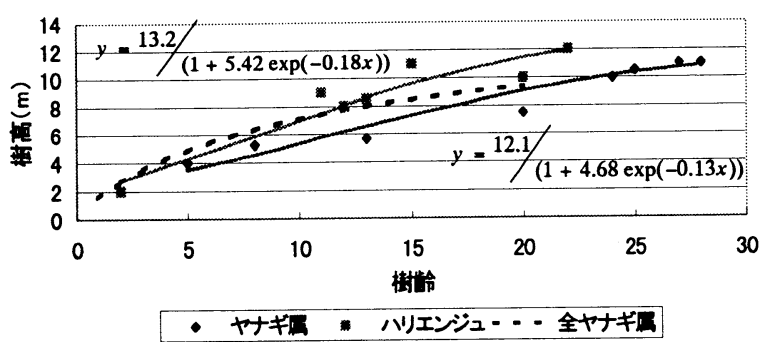

図-8 樹齢と樹高の関係

度が遅くなる．樹高については，両者ともある一定の樹 歯, ハリエンジュでは 10 年, コゴメヤナギでは 15 年か ら成長速度が遅くなることがわかる．さらに，ヤナギ属 について利根川・江戸川における調查結果 ${ }^{7)}$ と比較した ところ, 胸高直径については異なった結果となったが, 樹高については, 初期の成長速度に違いがあるものの, おおむね似た傾向を示している.これは，成長速度は， 地域，河床材料，土中の水分量等によって異なるためと 考えられる。

つぎに，河床材料と植物群落の種類の関係について調 べるため，河床表首材料のふるい分けを行い，図-9 のよ うな結果を得た。この図より，一見，扇状地性河道と見 えるが源流部の土砂生産と安定した侵食河道であるため, 多様性に富んだ河床形態を特徵づける河床材料特性が得 られた.

まず，裸地については，20m 以上の砂利・磁が $80 \%$ 以 上を占め, 植生が繁茂するには非常に難しい材料となつ ており，今後も植生が進入してくるとは考えにくい河床 材料特性となっている. また, 高木群落については, $75 \mathrm{~mm}$ 以上の粒径の大きな材料が $50 \%$ 近くを占めている. さら に, 草本群落と幼木群落の河床材料が非常に似ている傾 向を示していることが分かる. このように, 表首に磁が 見られる地点においても植生が確認できる要因としては, 表首マトリクスの細粒土砂含有率が $10 \%$ 以上多いため であり, 渡辺ら ${ }^{8)}$ の指摘する磷間隙中の小粒径材料の影 響か強いと考えられる.

図-10 は, 樹踚と立木密度の関係を表したものである. この図より立木密度と年輪の関係は, 指数関数で表され， 年輪が少ないところでは樹数が多く, 年輪の多いところ では少ないことがわかる．これは，樹木が大きくなるに つれ日光による光量や土中の栄養摂取等の問題のため ${ }^{9)}$, 淘汰されていくためと考えられる.

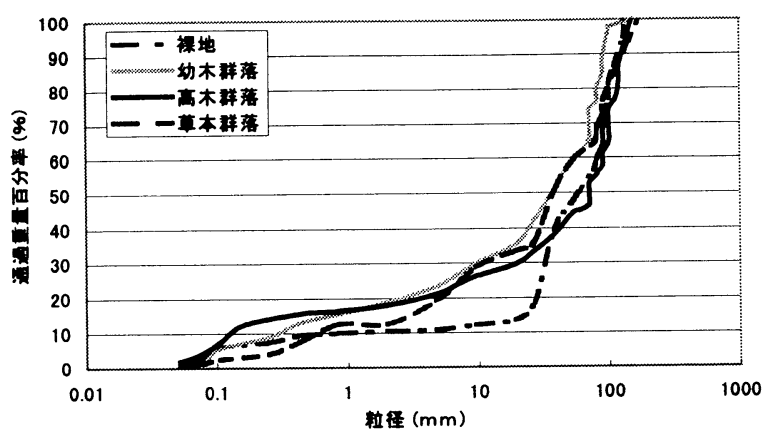

図-9 粒径加積曲線（上流部網流蛇行区間）

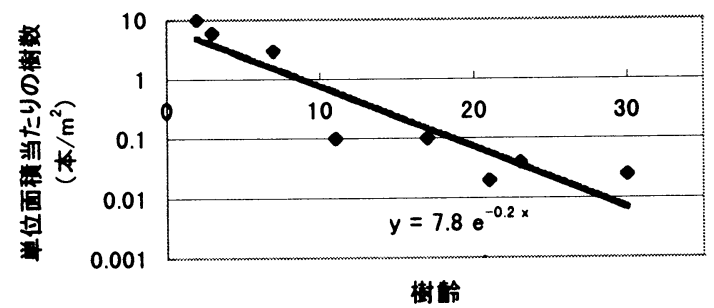

図-10 樹齢と立木密度の関係

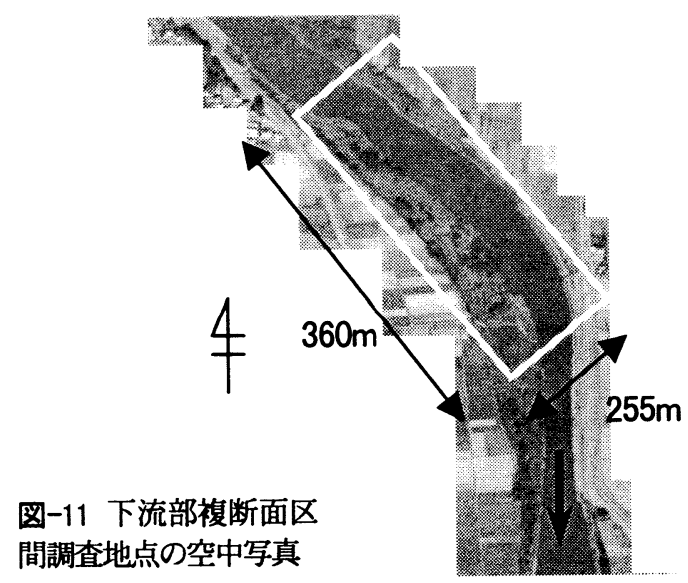

（2）下流部核断面区間（29.0km 地点）

下流部複断面区間の毎木調査を行った地点は, 樹種と してアカメヤナギ, 面積 $0.26 \mathrm{ha}$, 群落内の樹数は約 120 本, 調査地内の立木密度は 0.05 本/ $/ \mathrm{m}^{2}$ であった.

図-12 は, 図-11 の実線で囲まれた調査地点付近の植生 の経年変化を空中写真から判読したものを示したもので ある. この図より, 空中写真から判読した地点における 高木群落の植被度は, 1975 年で $3.8 \%, 1980$ 年で $4.3 \%$, 1994 年では $13.1 \%$ となっており, 増加の傾向にあること が分かる.

この地点は，図-3(B) より，高水敷または高水敷化して いるが, 比高が平均で $1.2 \mathrm{~m}$ と低く, 植生地帯の地盤高に 達する水位の生起確率年を計算したところ，1 日未満の冠 水継続時間を有する水位の出現頻度は，4 年に一度の確率 となった. また, 植生域冠水時の流量を Manning の平均 流速公式より計算したところ，図-13 のようになり，流量 が $1,800 \mathrm{~m}^{3} / \mathrm{s}$ を越えると植生域が冠水することが分かっ た.この図より,大規模な出水が発生したのは, 1966, 1972, 1979, 1981-82，1985 年の 6 回であり, 高水敷で有意な水 


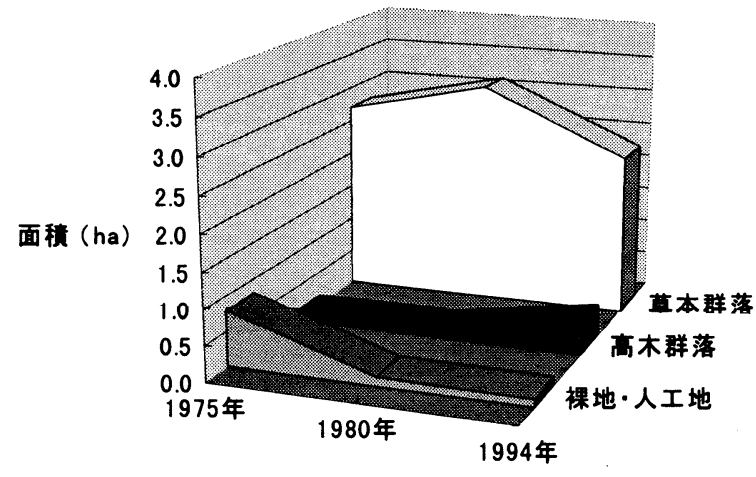

図-12 下流部複断面区間の植生経年変化

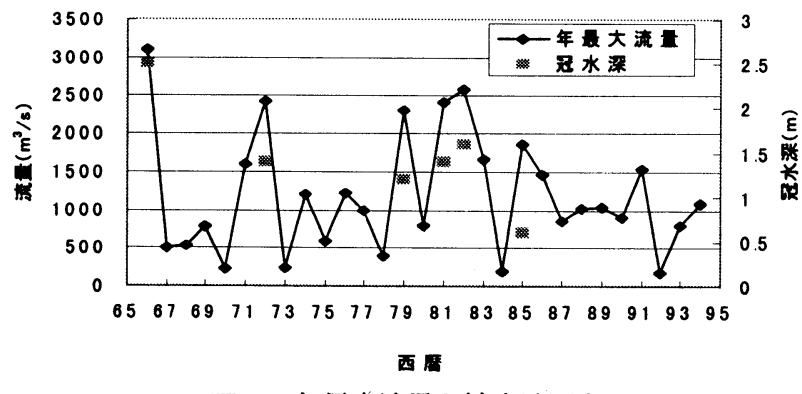

図-13 年最大流量と植生域冠水深

深が生じたのも, 上記の 6 回に 98 年の出水を含めた 7 回 であることが分かる. また, この 7 回の出水時の流水に よる外力モーメントと, それに対する高木の倒伏限界を 平均流速と高木の胸高直径を考慮した計算 ${ }^{10)}$ により表し たのが表-2 である. 過去の出水において, 倒伏・流出す る高木の倒伏限界モーメントから算出した樹路は, 出水 の規模にもよるが， 6 年以下のものが多くなっている.こ れは，若い高木は，支持根による摩擦抵抗と，根鉢によ るせん断抵抗が低く, 耐力が小さいため, 倒伏・流出す ると考えられる. さらに, アカメヤナギは深根型 ${ }^{10)}$ の樹 種であり, 根茎水平分布も分散しており樹齡が大きくな るにつれ流水に対する抵抗力も大きくなっていくと考え られる.

図-14 は樹齢分布を示したものである. 樹齢が 10〜20 年の高木が約 $80 \%$ 占めており, 多い点については, 図一 13 からも分かるように, 1983 年 1998 年の 15 年間, 植 生域が冠水する流量があまりなかったためと考えられ, 図-12 からも増加の傾向がつかめる.

また, 図-14 より, 幼木が少ないことについては, 現 地調査を行った 98 年 9 月の時点で, 同年 8 月の出水によ り植生域は冠水し, 水深は洪水痕跡より $1.2 \mathrm{~m}$ と推定でき, 河床に $0.6 \mathrm{~m}$ ほど土砂が堆積していた. そのため, 表-2に 示すように, 草本, 幼木群落は洪水流により流失または, 土砂の下敷きになり, 裸地化していた. しかし, 翌年 8 月に再度調查を行ったところ, 土砂が堆積し裸地化してい た地点は, 高茎草本であるヨシや， 1 年草のヒメムカシ ヨモギが高さ $2.0 \mathrm{~m}$ ほど繁茂しており, アカメヤナギの幼 木は見られなかった. 特にヨシは, 土中に埋没したり, 倒れてもしなやかであるため枯れずに残るため, 群落の 回復が速い II). よって, 裸地化後すぐに群落を形成した
表-2 出水時の高木群落の耐力（下流部複断面区間）

\begin{tabular}{|c|c|c|c|c|}
\hline 西暦 & $\begin{array}{c}\text { 平均流速 } \\
(\mathrm{m} / \mathrm{s})\end{array}$ & $\begin{array}{c}\text { 流水による外 } \\
\text { カモーメント } \\
(\mathrm{kg} \cdot \mathrm{m})\end{array}$ & $\begin{array}{c}\text { 外力モーメント } \\
\text { に対する胸高 } \\
\text { 直径 }(\mathrm{m})\end{array}$ & 樹龄 \\
\hline 1966 & 3.10 & 115 & 0.068 & 5 以下 \\
\hline 1972 & 2.99 & 92 & 0.061 & 4 以下 \\
\hline 1979 & 2.93 & 103 & 0.064 & 5 以下 \\
\hline 1981 & 2.99 & 131 & 0.073 & 5 以下 \\
\hline 1982 & 3.05 & 112 & 0.067 & 5 以下 \\
\hline 1985 & 2.65 & 15 & 0.025 & 1 以下 \\
\hline 1998 & 3.11 & 152 & 0.078 & 6 以下 \\
\hline
\end{tabular}

$\mathrm{n}=0.022, \mathrm{I}=1 / 2130$
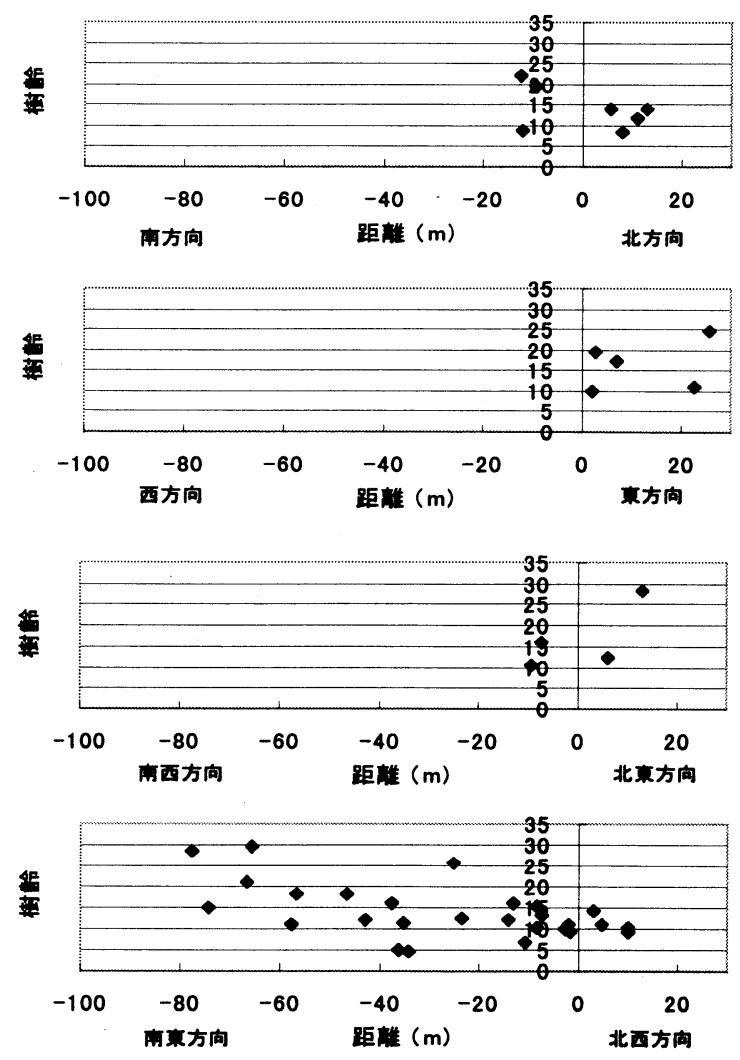

図-14 樹战分分布 （下流部複断面区間）

と考えられる. そのため, アカメヤナギの種子散布期で ある 5 月下旬の時点では, すでにヨシ群落が発達してお り, 日光の光量の関係もあり,幼木が成長しなかったと考 えられる.

このように,この地点では, 出水により擋乱され，草 本類などの影響もあり,幼木が育成することができず, 図-14 に示すように, 距離に関係なく比較的樹啮の大き い群落となっていると推察される.

さらに, 繁殖方法については, 根茎調査より栄養繁殖

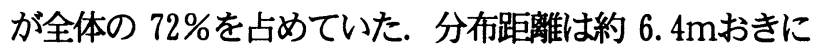
モザイク状に分布しており, 栄養繁殖による立木密度は 平均で 0.3 本 $/ \mathrm{m}^{2}$ であった.

表-3 は, 出水時に高木の倒伏と関係のある樹高と樹冠 の関係についてまとめたものである. 低水路側や高水敷 側などの樹林地外側に立地する高木は，樹冠高（樹高-枝 
表-3 樹高と樹冠の関係（下流部複断面区間）

\begin{tabular}{|c|c|c|c|c|c|}
\hline 高木の位貫 & $\begin{array}{c}\text { 樹高 } \\
(\mathrm{m})\end{array}$ & $\begin{array}{c}\text { 枝下高 } \\
(\mathrm{m})\end{array}$ & $\begin{array}{c}\text { 樹冠高 } \\
(\mathrm{m})\end{array}$ & $\begin{array}{c}\text { 樹冠幅 } \\
(\mathrm{m})\end{array}$ & $\begin{array}{c}\text { 樹冠高/樹高 } \\
(\%)\end{array}$ \\
\hline 低水路側 & 10.0 & 4.0 & 6.0 & 2.5 & 60 \\
\hline 低水路側 & 8.0 & 4.4 & 3.6 & 3.9 & 45 \\
\hline 中央 & 11.0 & 8.2 & 2.8 & 1.2 & 28 \\
\hline 中央 & 10.5 & 8.3 & 2.2 & 0.9 & 22 \\
\hline 高水数側 & 10.0 & 5.5 & 4.5 & 4.2 & 41 \\
\hline 高水糤側 & 10.0 & 6.0 & 4.0 & 5.4 & 40 \\
\hline
\end{tabular}

下高) が高く, よって多く枝別れしていることがわかる. これは, より多くの日光を得るためと考えられる. また, 中央に立地するものについては，樹冠高が低く，幅も狭 く枝別れが少ない，また，外側に比べやや樹高が高くな つている.

図-15 は, 河床の表首材料のふるい分け試験の結果を 示したものである. 全体の傾向としては, シルト, 細砂 が 9 割以上を占めている. 去年の出水により土砂が堆積 したため, 植生との関係はあまりないと考えられるが, 過去の出水時も同様の堆積傾向であるとすれば, 深さ方 向の材料の分布は表層と似た材料特性であると考えられ る. まず, 高木群落内の河床材料特性は, 全域にわたり 土砂が堆積しており, 群落内の立木密度は幼木がないこ とから全域にわたり同じ程度 $\left(0.05\right.$ 本 $\left./ \mathrm{m}^{3}\right)$ であるが, 群 落の上流側より下流側のほうが粒径の小さい材料が堆積 している. また, 群落の外側 (堤防側) の 2 地点では, 洪水前にはヨシが密生 (単位面積当たり 76 本)しており, 堆積した土砂の材料特性は, 似た傾向を示している.

\section{5. 結論}

河道特性，水理的影響の異なる鬼怒川の 2 地点におけ る植生調査の主要な結果は次のようである.

1）両区間において高木群落面積は拡大傾向にある.

2）上流部網流蛇行区間において, 初期成長速度の速い ハリエンジュは, 群落内の優占種となる.

3）河床材料特性が樹種に関わっており, 両区間におい て河床材料特性に適した樹種が見られた。

4）両区間の優占種の繁殖方法としては，栄養繁殖と風 散布が確認され, 栄盖繁殖は上流部網流蛇行区間では, ハリエンジュで $85 \%$, 下流部複断面区間のアカメヤ

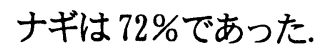

$5 ＼mathrm{~ ） 洪 水 な と ゙ の 水 理 的 影 響 に つ い て は ， 上 流 部 網 流 蛇 行 ~}$ 区間では, 近年冠水は確認されていないため, 樹龄の 分布が広い年代にわたっていた. また，下流部複断面 区間では，植生域を冠水する出水が 1985 年まで頻繁 に起きており, 98 年の出水の影響もあり, 樹㱓分布 は 10 から 20 年の高木が多い構造となっている.

6）下流部複断面区間において, 出水時の外力モ一メン トにより, 出水規模にもよるが, 樹齢 6 年以下の高木 が倒伏，流出したことが推察された.

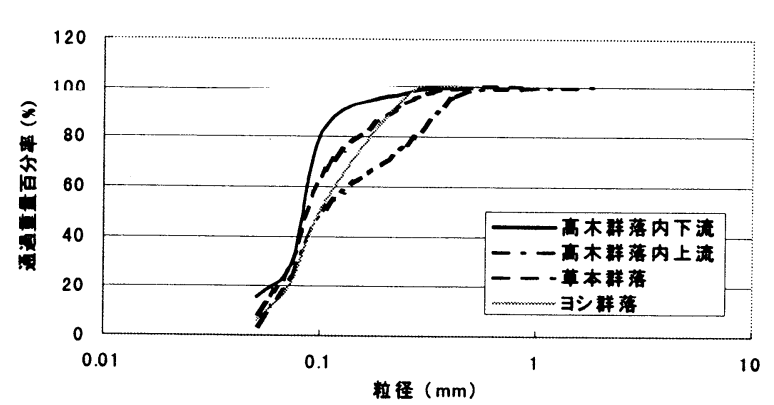

図-15 粒径加積曲線 （下流部複断面区間）

\section{6. おわりに}

本研究では, 鬼怒川流域での高木群落の実態を調べた 結果, 群落の形成·発展と河道特性·水理的影響の関係を 明らかにすることができた，今後は，河道の蛇行形態の 影響を考慮するため急流部において調査地点を 2 ヶ所追 加し, また, 草本類の生産との関係, 他河川の事例を入 れて一般化したいと考えている.

\section{参考文献}

1) PACALA, S.W - C. D. CANHAM - A. J. SILANDER : Forest models defined by field measurements: I The design of a northeastern forest simulator, Can. J.For. Res. , 23, pp. 1980-1989, 1993

2 ）岡部健士·鎌田磨人·湯城豊勝·林雅隆 : 交互砂州上の植生 之河状履歴の相互関係 -吉野川における現地調査-, 水工学 論文集, 第 40 巻, pp. 205-212, 1996

$3 ）$ 李参熙・藤田光一・塚原隆夫 ·渡辺敏 $\cdot$ 山本晃一・望月達 也: 磁床河川の樹林化に果たす洪水と細粒土砂流送の役割, 水工学論文集, 第 42 巻, pp. 433-438, 1998

4）砂田憲吾 - 岩本尚・渡辺勝彦 : 出水履歴之河道特性が植生 域の長期変動に及ほす影響に関する基礎的研究, 水工学論 文集，第 42 巻, pp. 451-456, 1998

5）建設省土木研究所河川部河川研究室 : 河道特性による植物 群落の分類 一利根川と鬼怒川を実例として一, 土木研究所資 料, 土木研究所資料 3249 号, 1994

6）財)リバーフロント整備センター : 河川水辺の国勢調査年 鑑, 山海堂, 1996

7）池内幸司 - 田口隆男 - 原田圭助 : 河道内樹林の育成特性に 関する基礎研究, リバーフロント研究所報告, No.4, pp. 155-167, 1998

8）渡辺敏・藤田光一・塚原隆夫 : 安定した砂磷州における草 本植生発達の有無を分ける要因, 水工学論文集, 第 42 巻, pp. 439-444, 1998

9) 山本進一 : 森林の更新 一そのパターンとプロセスー, 遺 伀, 38 巻 4 号, pp. 43-50, 1984

10）財)リバーフロント整備センター : 河道内の樹木の伐採·植 樹のためのガイドライン(案), 山海堂, 1994

11）奥田重俊・佐々木寧 : 河川環境之水辺植物 一植生の保全 と管理一, ソフトサイエンス社, 1996

(1999.9. 30 受付) 